DOI: $10.1515 / \mathrm{rpp}-2015-0036$

Doctor of Pedagogical Sciences, Full Professor, NATALIYA MUKAN National University Lviv Polytechnic, Ukraine Address: 12 Stepan Bandera St., Lviv, 79013, Ukraine E-mail: nmukan@polynet.lviv.ua

$\mathrm{PhD}$ in Pedagogical Sciences, Assistant Professor, MARIANNA HAVRYLYUK National University Lviv Polytechnic, Ukraine Address: 12 Stepan Bandera St., Lviv, 79013, Ukraine E-mail: marihor02@mail.ru

Instructor, MARYANA PROTS

National University Lviv Polytechnic, Ukraine Address: 12 Stepan Bandera St., Lviv, 79013, Ukraine E-mail: anyaram7@yahoo.com

\title{
LEADERSHIP IN R\&D ACTIVITY IN ENGLISH AND WELSH UNIVERSITIES
}

\begin{abstract}
In the article, leadership in $R \& D$ activity in English and Welsh universities has been studied. The main objectives of the article are defined as following: to analyze the scientific literature which highlights different aspects of the problem under research, to identify the specificity of leadership practice in $R \& D$, and to develop the recommendations for leadership development in Ukrainian universities. Leadership in higher education has been studied by foreign and domestic scientists, especially, methodology of comparative education (C. Bargh, N. Bidyuk, N. Mukan, A. Sbruyeva); continuous professional education (J. Barge, A. Kuzminskyy, P. Lorange, N. Nychkalo); leadership in education (J. Bareham, L. Danylenko, L. Karamushka, N. Kolominskyy, O. Marmaza); leaders' training (A. Borysova, $V$. Hromovyy) etc. In Ukraine the problem of leadership in $R \& D$ has not been studied yet. The methodology of our research comprises theoretical (comparative and historical method, logical method, analysis and synthesis), and applied (conversations and dialogues) methods. The research results have been presented: the fundamentals of leadership in $R \& D$ and its specificity in England and Wales; the factors of leadership in R\&D of English and Welsh universities; the recommendations for leadership development in Ukrainian universities.

Key words: theoretical framework, leadership, leadership theories, leadership in $R \& D$, leadership models, distributed leadership, higher education, leader.

\section{INTRODUCTION}

Intensification of research at the beginning of the $21^{\text {st }}$ century can be described as an international phenomenon. Among its distinctive characteristic one can find tradition of foreign excellence centers development. These institutions have the objectives to train scientists and ensure the possibilities for international exchange of experience. International cooperation in $R \& D$ includes researchers and students engaged in research in accordance with the curriculum of educational qualification of Bachelor, Master, and Doctor Degrees. Leading universities in England and Wales are entrusted with the task of innovative development of a knowledge society. Their activities are implemented according to the trends of international educational area. Changes in social characteristic of students
\end{abstract}


necessitate orientation of the university activities towards the needs and interests of educational services consumers. Thus, professionalization of university services and active implementation of scientific development take place. The impact of globalization and regionalization on the development of university education requires the expansion and application of entrepreneurship and leadership potential. The universities in England and Wales introduce innovations in teaching, managerial and research activities, based on the widespread use of leadership. Therefore, theoretical and practical experience of English and Welsh universities deserves attention and requires the objective study.

In Ukraine, the leadership of university teaching staff is underdeveloped. It needs to be noted that conducting of comparative research, study of foreign experience makes it possible to identify the advantages and disadvantages of a certain phenomenon or process, in particular the advantages of the use of leadership in university R\&D activity. Thus, the relevance and insufficient study of the issue in the national pedagogical science has determined the choice of our research topic.

\section{THE AIM OF THE STUDY}

The analysis of leadership in R\&D activity in English and Welsh universities is the research aim. The following objectives have been defined: 1) to analyze the scientific literature which highlights different aspects of the problem under research; 2) to identify the specificity of leadership practice in $R \& D$; 3) to develop the recommendations for leadership development in Ukrainian universities.

\section{THEORETICAL FRAMEWORK AND RESEARCH METHODS}

The following theories, concepts and scientific approaches form the theoretical framework of our research: fundamentals of modern philosophy of education (V. Andrushchenko, S. Graham, T. Huston, V. Kremen, I. Zyazyun); methodology of comparative pedagogy (N. Avshenyuk, C. Bargh, N. Bidyuk, T. Desyatov, O. Lokshyna, N. Mukan, Y. Neumann, L. Pukhovska, A. Sbruyeva); continuous professional education (J. Barge, A. Kusminskyy, P. Lorange, N. Nychkalo); leadership in educational and scientific spheres (J. Bareham, L. Danylenko, V. Hromovyy, L. Karamushka, P. Knowles, O. Marmaza, H. Syrotenko, K. Ushakov); leaders' training (A. Borysova, V. Hromovyy, O. Zhyhlo).

The conducted literature review covered research theories relevant to the scientific problem: classification of leadership models (K. Leithwood, B. Levin); instructional leadership (P. Hallinger); transformational leadership (B. Avolio, F. Yammarino); moral leadership (P. Begley, O. Johansson, P. Leonard); participative leadership (K. Duke, P. Gronn, J. York-Barr); managerial and strategic leadership (J. Rost); leadership development program (D. Campbell, C. Mabey, M. Ramirez); leadership development methods and forms (F. Barbeite, J. Burgoyne, P. Kettley, T. Maurer, D. Mitchell, J. Storey).

Different aspects of leadership in higher education have been the matter of scientific concern of such domestic scientists: leadership development (M. Ananchenko, T. Bazarov, N. Bashmakov, V. Hromovyy, I. Myskiv); management and leadership (V. Androsyuk, V. Bereka, O. Halus, O. Hurova, A. Kobera, V. Kryzhko, N. Mukan); leader training (A. Borysova, O. Vasylkova); leadership development program (M. Havrylyuk, L. Karamushka, V. Kiyashko, O. Kulish, N. Marakhovska); management and leadership culture (N. Kolominskyy, O. Marmaza).

The results of comparative analysis of education in different countries highlighted in scientific works of such researchers as Ya. Belmaz, H. Byhar, C. Chervonetska, N. Chorna O. Devchenko, Yu. Kishchenko, T. Koshmanova, O. Leontyeva, M. Leshchenko, N. Moroz, H. Pohromska, A. Sokolova, S. Synenko O. Zabolotna, I. Zadorozhna have been significant for our research. 
The study employs different theoretical and applied research methods. The comparative method has been used to study educational documents, normative and legislative framework of higher education, scientific and pedagogical literature, academic standards for university staff; logical method - to single out the basic concepts of leadership in R\&D; induction and deduction - to formulate the statements and generalize the theoretical and matter-of-fact material. Among applied methods, we have used conversations and dialogues with the universities faculty in England and Wales for gathering primary pedagogical information.

\section{RESULTS}

Investment in science and innovation is not an intellectual treasure of developed countries, but economic and social necessity, a required element of economic success. A modern university is an integral element of ensuring economic and social welfare of the country and the region, since it invests, teaches students, conducts scientific research. Universities are regarded as the main form of investment in science and innovation, as they are the foundation of the knowledge economy. Research and knowledge sharing are the key benefits of universities in England and Wales. They form the basis for innovative environment. In the document "The future of higher education" (The future of higher education, 2003) it is stated that R\&D form long-term foundation for innovations, which serve as the basis for improvement of the living standards, productivity and economic development of England.

Among the main issues that are included in the development strategy of R\&D activity of European universities there are the following: giving preference to skill and improving university activity; formulation of sectoral priorities in correspondence with the existing R\&D base and the investment opportunities for its improvement; establishment of internal horizontal communication, interdisciplinary relations and mutually beneficial cooperation; creation and dissemination of knowledge, implementation of research results in industry and business, creation of innovation mentality; formation of regional network; recruiting of outstanding scientists, and increasing requirements for training of future scientists (Reichert, 2006).

Exploring the features of R\&D activity in European universities, S. Reichert (Reichert, 2006) has noted that elaboration of development strategy of R\&D activity in modern universities is carried out under certain conditions. Among them the author has identified $\mathrm{R} \& \mathrm{D}$ priorities of national or regional level; R\&D priorities of government agencies that provide the bulk of university funding; R\&D priorities of regional, public or private organizations and institutions providing investment funds for university; innovative R\&D projects.

Among the main reasons that cause the elaboration of development strategy of R\&D activity, building and support of sufficient research base of universities in England and Wales, there is an enhancement of international competition in higher education area, especially in the fields of natural and technical sciences.

At the present time, new assessment system of scientific research quality "Research Excellence Framework" (Research excellence framework, 2010) is approbated in the universities of England and Wales. The main tasks of the system include providing information on the distribution of research funding in the higher education system of the country; information on the assessment criteria and ranking; reporting on the use of public funds for R\&D and demonstration of its advantages.

The key elements of the assessment process are the quality of scientific research, measured according to international standards of excellence; the further impact of the research results; the viability of research environment. 
Traditionally, research laboratories of universities in England and Wales had been employing scientists and engineers with special technical skills and abilities (Farris \& Cordero, 2002). At the beginning of the $21^{\text {st }}$ century, requirements for the competence of the workers of the scientific field changed. To work in interdisciplinary research team, scientists with leadership qualities, knowledge, skills and abilities are needed not only for conducting research, but also for functioning in market conditions (Cordero, 1996; Pelled \& Adler, 1994; Rosenbaum, 1990). Activity in conditions of geographical distance between team members (multinational research projects and programs) requires skills and abilities of modern information and communication technologies use in order to establish a permanent communication (Kayworth \& Leidner, 2001-2002). We should mention that demographic diversification requires multicultural training as well.

It is to be noted that for many years technical managers directed the activities of scientists using the command style and different control systems, thus providing supervision; activity planning; defining the procedures and rules. Today, however, technical managers define general goals and objectives, create a favorable working environment (James, 2002), (Jassawalla \& Sashittal, 2000), (Petroni, 2000). They perform two important functions: introduce changes and carry out managerial functions. The introduction of changes is implemented by providing incentive working environment for scientists, which is characterized by complex tasks, delegation of authority, clear definition of goals and objectives, opportunity for personal professional development (Cordero, Farris \& DiTomaso, 2002). The current highly competitive R\&D environment requires the implementation of leadership potential (James, 2002; Jassawalla \& Sashittal, 2000).

In terms of the university research laboratory a leader performs a number of functions covering the development of strategy of R\&D activity, motivating staff, and budget management. This means that the leader develops the vision and main developmental directions of the laboratory activity. Building a constructive relationship within the team includes such factors as creating and managing a team of scientists; formation of an environment in which employees can provide and receive feedback on activities; motivation and support of the MA students, graduate students, and technical workers; authority delegation to other employees, if possible; fair decision-making and conflict management; communication and ability to listen to and hear the opinions of colleagues; perception of multiculturalism and understanding the needs of others.

One of the leader's responsibilities is also to manage the activity of the scientists. In addition to basic knowledge of scientific tools and research processes used in the laboratory, the leader should be able to develop projects and determine its time frame; develop R\&D budgets; write proposals for grants and generate reports; teach subjects; simultaneously balance various needs (Guberman, Saks, Shapiro \& Torchia, 2006).

Scientists of the universities in England and Wales are workers of the branch of knowledge creation, and knowledge is the main resource of competitive advantage. Knowledge management requires the availability of such factors as culture and structure of the organization of knowledge creation in the university conditions. In other words, among the main tasks of the university leaders there is the task to ensure the development of culture, the core values of which are the creation of knowledge and its dissemination, support from the university leaders for knowledge management, adoption of support measures for the knowledge management system and so on. Also, of particular importance there is the organizational structure of the university, which promotes the establishment of relationships between scientists from different departments, the formation of interdisciplinary research teams. 
Leadership in R\&D activity is a facilitating process of new knowledge creation and effective use of public resources needed for research.

Considering the initial phase of leadership in the national reality, the study of the theory and practice of using leadership in R\&D activity at the universities of England and Wales, the analysis of ideas and experience of the countries surveyed, provide the opportunity to develop methodological recommendations for their use while implementing the leadership of university staff in Ukraine. In the knowledge society universities are the most important mechanism of generation, storage, distribution, and transformation of knowledge. One of the main tasks of leadership in university is the organization of educational institution, aimed at implementation of strategic goals, gaining excellence in R\&D and teaching activities in order to perform the basic function, as assigned to university by society.

In modern university, special attention should be paid to the research sector, which is considered as a powerful resource of the country's economic development at the regional, national and international levels. In this regard, strong government support should be provided in the form of financial investment, and also by facilitating the opening of cooperation centers between universities and business institutions. Leadership in R\&D activity needs to be directed towards the implementation of the development strategy research activity. Leaders in the field of research should contribute to the building of a constructive environment, in which knowledge is created, disseminated, and used. This requires mastering appropriate knowledge, formation and development of skills and abilities to perform functions specific for entrepreneurship.

\section{CONCLUSIONS}

The universities of England and Wales are powerful economic institutions, depositories of intellectual and leadership potential, which is a key factor for business and highly skilled human capital development. They play one of the most important roles in society, and have the ability to provide intellectual leadership within it through the creation and dissemination of knowledge. Leadership in R\&D activity in the universities is based on correspondence to scientific priorities of innovative projects, private investors, and state authorities at regional and national levels. The universities build their own development strategy of R\&D activity that involves the use of leadership potential. Leadership in R\&D activity in universities of England and Wales includes such factors as establishing international scientific cooperation; ensuring the availability of information resources; access to research results, taking into account the copyright law; development of procedures and exchange of experience on ensuring the availability; use and management of scientific data according to the recommendations of the Organization for Economic Cooperation and Development; ensuring the availability of digital objects created at the local level; development of information literacy; use of modern information and communication technologies potential to improve the research process.

Prospects for future research include the study of leadership standards in R\&D; development of training programs for scientists-leaders in the system of continuous professional education.

\section{REFERENCES}

1. Cordero, R. (1999). Developing the knowledge and skills of R\&D professionals to achieve process outcomes in cross-functional teams. The journal of high technology management research, Volume 10, Issue 1, p. 61-78. 
2. Cordero, R., Farris, G. \& DiTomaso, N. (2002). The technical supervisor as captain and catalyst. In: Proceedings of the 2002 International engineering management conference Managing Technology for the New Economy (18-20.08.2002). Cambridge, p. 274-279.

3. Farris, G. \& Cordero, R. (2002). What do we know about managing scientists and engineers: a review of recent literature. Research technology management, Volume 45, Issue 6, p. 13-25.

4. Guberman, J. Saks, J., Shapiro, B. \& Torchia, M. (2006). Making the right moves. A practical guide to scientific management for postdocs and new faculty. Howard Hughes Medical Institute, Burroughs Welcome Fund, p. 256.

5. James, W. (2002). Best HR practices for today's innovation management. Researchtechnology management, January-February, p. 57-60.

6. Jassawalla, A. \& Sashittal, H. (Winter, 2000). Strategies of effective new product team leaders. California management review, Volume 42, Issue 2, p. 34-51

7. Kayworth, T. \& Leidner, D. (Winter, 2001-2002). Leadership effectiveness in global virtual teams. Journal of management information systems, Volume 18, Issue 3, p. 7-40.

8. Pelled, L. \& Adler, P. (1994). Antecedents of intergroup confict in multifunctional product development teams: a conceptual approach. IEEE transactions on engineering management, Volume 41, Issue 1, p. 21-28.

9. Petroni, A. (2000). Myths and misconceptions in current engineers' management practices. Team performance management, No. 6, p. 15-24.

10. Reichert, S. (2006). Research strategy development and management at European universities. Brussels : The European University association, p. 48.

11. Research excellence framework: consultation outcomes. (March, 2010). Welsh Assembly Government, p. 11.

12. Rosenbaum, B. (January-February, 1990). How successful technical professionals achieve results. Research-technology management, p. 24-26.

13. The future of higher education. (January, 2003). DfES, p. 105.

14. Гаврилюк, М. В. (2011). Феномен лідерства в університетській освіті. На матеріалах Англії та Уельсу [Leadership phenomenon in the university education. On the materials of England and Wales]. Львів: Видавництво Національного університету «Львівська політехніка», p. 132 (in Ukrainian). 